\title{
STATE SUPPORT OF AGRICULTURE OF RUSSIA - SEARCH OF APPROACHES TO BUILD MODERN, EFFECTIVE MODEL
}

\author{
Dmitriy Loginov, Vladimir Stepanyan \\ Vyatka State University, Russia \\ doctorloginov@mail.ru, psysop@mail.ru
}

\begin{abstract}
Every state is interested in creation of such conditions for the national agriculture, which would provide the best economic outcome for the industry within the country and abroad. The system of state support for Russian agriculture needs regular improvement due to constantly changing conditions. Due to the difficult climatic conditions, it is difficult for Russian food products to compete with imported food, so the system of state support for agriculture should focus on ensuring the competitiveness of the products. The study of various approaches to state support for Russia's agriculture makes it possible to develop the most effective solutions and practical recommendations. The introduction of data in the work of the recommendations will not only help increase the efficiency of the distribution of funds, but also help achieve the early achievement of the targets set in the Russian food security strategy. This article is devoted to the study of state support for agriculture and its effectiveness in the current conditions of "sanctions confrontation" and an active policy of import substitution. In this paper, various mechanisms of state support not only for the agricultural economy of Russia, but also for the European Union are considered. On the basis of the data from the Ministry of Agriculture of the Russian Federation, the statistical bureau of the European Union and the Organization for Economic Cooperation and Development, an analysis of the mechanisms of state support has been conducted, and recommendations have been made to improve the effectiveness of state support for the Russian agriculture. Competent state support on the basis of conservative scenarios will be able to restore the efficiency of the agro-industrial complex, and with internal growth of consumption of agricultural products, preserve the country's food security, increase income and reduce unemployment in rural areas.
\end{abstract}

Key words: agricultural policy, budgetary support, import substitution, government spending.

\section{Introduction}

Historically, Russia has held a leading position in the ranking of states producing and exporting agricultural products. At the present stage, domestic agriculture provides $3.7 \%$ of GDP and about $8 \%$ of employment. In the differentiated structure of Russian agriculture has been developed industry for the production of crops, horticulture, livestock, poultry, and etc. With the collapse of the Soviet Union the situation changed, the state from the producer has passed to the rank of importers of agricultural products. Along with the reduction in production volumes of agriculture the distress of the rural territories began, a stop of adjacent productions, such as agricultural mechanical engineering and chemical production, has begun. As a result of decline in quality of life of country people outflow of human potential to the cities has begun.

Agriculture has a number of specific features that make it unable, through the realization of produced products, to earn sufficient income to preserve land as the main source of production, recover the costs incurred and social development in rural areas. In the current market environment, state support is becoming an objective necessity for the survival and development of agriculture.

\section{Materials and methods}

The basis of the materials of this study are the data characterizing the results of agricultural development in different countries of the world, primarily in Russia and European countries. In addition, the authors analyze the system of state support for agriculture in Russia, trying to compare with the countries of the European Union. A methodological approach is being implemented, such as comparing the results of the development of the studied sector of the economy with the intensity and quality of measures of its state support in order to draw conclusions about the most appropriate methods of state support for agriculture in the future.

The authors carry out the presented analysis in the context of new challenges to Russian agriculture related to the need for import substitution of many food products in the domestic market. The research methods include analysis and synthesis of scientific publications on the topic, analysis of statistical materials published by both Russian and foreign sources. For comparative assessment of 
levels of the state support of agriculture in Russia and Europe comparison of gross production of agriculture with the sum of the state budget funds used for support of agriculture is applied

\section{Results}

The state support - an indispensable condition of existence and growth of modern agro-industrial production and food market what experience of the leading world powers testifies to [12].

In comparison with industry, agriculture has a number of specific features, such as the cyclical nature and seasonality of reproduction of products. Agriculture in comparison with industry is less technological, more static and less profitable, and therefore, provides a relatively less profitability. Negative factors present in the agro-industrial complex, longer payback periods, and lower returns, compared to other, more technologically advanced industries, attract less investment in the industry, which requires substantial state support for sustainable development of the agro-industrial complex.

According to A.I. Kostyaev, the mismatch of the working period, the production period and the period of sale of products requires huge borrowed funds to ensure timely conduct of seasonal field work, while the lending rates of commercial banks in a free market are unacceptable for most agricultural producers.

The cost of credit resources is prohibitive: the interest rate is almost twice the level of profitability of agricultural producers, even taking into account subsidies. Therefore, along with the issue of raising the profitability of the industry, it is necessary to significantly adjust the lending mechanism. After all, today, up to $65 \%$ of profits are spent on servicing loans in agriculture, while only $14 \%$ in the extractive branches of the fuel and energy complex (oil and gas industry) [15].

The non-competitiveness of agriculture in comparison with other sectors of the economy, where production and economic processes are more deterministic, requires substantial government support [13].

The volume of agricultural subsidies in Russia is much lower than in Europe and the US, which once again confirms the need to address the problem of efficient use of limited budget resources to support the income of agricultural producers [14].

In the food market of the Russian Federation at the present time there is a tough competition between domestic agricultural commodities and food products imported, which, thanks to significant state support of the countries where these goods are produced, have certain competitive advantages over Russian agricultural products. Domestic farmers are not quite competitive, as the cost of agricultural production laid the high monopoly prices dictated by the suppliers of the means of production, such as fuels and lubricants, fertilizers, electricity, etc.

For the state, the agro-industrial complex is an instrument for implementing the food security strategy, a mechanism for ensuring the food independence of our country. The state, using the means of state regulation, should stimulate the development of the domestic agrarian sector, reduce the development gap between agriculture and other sectors of the economy, and in the standard of living between the urban and rural population.

Production activities in the agro-industrial complex, and, first of all, in plant-growing are associated with such uncontrollable by people factors as torrential rains, droughts, hurricane winds or damage to crops by hail. As a result of adverse weather conditions, the agro-industrial complex can incur significant costs. Minimizing the risks of such phenomena is possible under the agricultural insurance with state participation. At present, agricultural insurance programs with state participation are being implemented in Russia, but their volume covers no more than $20 \%$ of crops.

Government support for insurance is a much more effective tool than financial assistance provided in unfavorable years in the form of additional loans, subsidies, deferrals and direct monetary compensation. Insurance is one of the means, the use of which does not violate the WTO rules and can serve as an effective tool for stabilizing the incomes of agricultural producers [2].

The functioning of the agricultural sector is largely determined by macroeconomic indicators, which currently show stagnating dynamics.

According to the Ministry of Economic Development of the Russian Federation, the industrial production index in January-July 2016 decreased by 0.5 percentage points to the same period in 2016 . 
The index of production of agricultural products for the period January-July 2016 increased by 0.7 percentage points to the corresponding period of the previous year. Real disposable money income of the population decreased by $0.6 \%$, the real wages of employees decreased by $0.2 \%$, the turnover of retail trade decreased by $0.1 \%$. [7]. According to the federal service of state statistics, the consumer price index for January-July 2016 to January-July 2015 was 107.8 [16]. The cost of a barrel of Brent crude oil in July 2016 decreased by $6.9 \%$ to the value in July 2015. Based on the data of the Ministry of Agriculture of the Russian Federation for the period January-July 2016, the prices for AI-92 gasoline increased by $19.6 \%$, on diesel fuel - by $13.9 \%$ [8]. The reduction in the cost of Brent crude oil on world markets was not accompanied by a decrease in the cost of petroleum products on the domestic market of the Russian Federation. Investments in fixed assets for the development of agriculture in actually effective prices decreased by $5.5 \%$ in 2015 compared to 2014 [4].

The current situation in the agro-industrial complex of the Russian Federation does not contributes to the development of the agro-industry, low profitability and the manifestation of various kinds of risks expand and enhance the problems of the effective functioning of the agro-industrial complex and its main branch - agriculture. In consideration of the foregoing, we can state the fact that agro-industrial complex cannot fully realize its reproductive potential, and most of the agricultural commodity producers are does not unable to introduce modern innovative technologies to increase the efficiency and competitiveness of products, that is, technologies that allow to modernize and further develop the agro-industrial complex on an innovative model, meeting modern economic requirements for ensuring food security and import substitution.

Agriculture of most countries in the world is subsidized by their governments. State support is also needed for the development of domestic agriculture. By the level of state support of agroindustrial complex our country lags far behind the developed countries. Subsidies in the EU countries reach half of the value of commodity products of farmers. In 2015, state support for the Russian agroindustrial complex amounted to 42.9 billion rubles, the proceeds from the sale of agricultural products amounted to 5164.6 billion rubles. Thus, state support was only 0.8 kopecks per one ruble of revenue received in the industry.

In the developed countries and the states of the European Union state support of agricultural producers in the price of agricultural products is on average $33 \%$, and Russia - not more than $6.8 \%$ [6].

At the present time, the most sharply there are questions of a role of the state in regulation of the Russian agro-industrial complex. Budgetary, that is, state financing is necessary since agrarians, because of their production specifics, cannot profitably for oneself participate in inter-industry competition. Nonequivalence in the exchange of agricultural goods for goods produced by other sectors of the economy in combination with low purchasing power of the population leads to low investment attractiveness of the industry, which in the compartment with other negative factors makes the agricultural sector low-profitable.

Based on the functions of the state budget, each branch of the economy should have its own specific shares, being both a source of budget formation and a consumer of funds.

The agro-industrial complex is not only a source for providing the population with food, but also provides the production sector with raw materials. The development of agriculture provides a multiplicative effect in other areas of the national economy.

Government support to farmers through budgetary financing would substantially increase the production of agricultural products, fill the market with high-quality products that meet domestic food security standards.

According to V. I. Kashin, one working place in the agro-industrial provides five or six jobs in other industries, and one percent of agricultural output growth gives the whole country's economy growth 2-2.5\%. [5].

Agriculture is one of the key branches of the economy of the European Union, which quickly overcame the aftermath of the Second World War, becoming the largest producer and exporter of agricultural products, the successful development of European agriculture became possible due to highly developed and efficient agricultural policy. 
Common agricultural policy of the European Union valid since 1962 is funded through the European Agricultural Guidance and Guarantee Fund in agriculture (EAGGF), which has been functioning since July 1964. This policy is a system of subsidies paid to farmers in the EU. The main objectives of the common agricultural policy (CAP) of the European Union is guaranteeing the production of sufficient food and ensuring fair standard of living of people engaged in agriculture.

The main objective of the CAP of the European Union is to regulate markets, ensure economic growth in the EU member states and develop agro-industrial production.

The agreement on the reform in the field of a unified agricultural policy, achieved in 2013, provides for state support in the period from 2014 to 2020 in the amount of 408.31 billion euros at current prices, or 362.79 billion euros in 2011 prices, which is $37.8 \%$ of the EU budget [11].

Common agricultural policy has two levels of government support. The first level is the direct support and costs associated with the organization and regulation of the market. From 2014 to 2020 in the EU budget on the spending CAP of the first level provides 312.74 billion euros in current prices, or 277.85 billion euros in 2011 prices. On the second level there are costs associated with the development of the rural areas 2014 to 2020 in the EU budget on the spending CAP of the second level provided 95.58 billion euros in current prices, or 84.94 billion euros in 2011 prices.

The first level of agricultural support is described in the paragraph number four Overview of CAP Reform 2014-2020, which refers to the change in the approach to subsidies for European farmers. The new strategy of state support envisages a departure from the measures envisaged under the first component (Pillar I), i.e. subsidizing the cultivation of certain crops and shifting from the distribution of direct payments in favor of financing of the means provided within the second component (Pillar II). The support mechanisms themselves are established by Member States, depending on the priorities identified in their state agricultural subsidy programmes.

The second level of agrarian support is described in the paragraph number five Overview of CAP Reform 2014-2020, it follows that the development of agricultural areas is subsidized, taking into account their individual characteristics, the diversity of cultivated crops, potential yields, climatic, ecological, as well as socio-economic conditions.

The European Union has established a clear framework of regulatory and budgetary constraints to define rules for the protection of sovereign markets, and this mechanism is designed to protect the European Union market from trade restrictions among states parties.

The current model of the CAP is the most effective, focused and consistent, since the integrated approach supports the current structure and both levels of support complement each other and allow you to more effectively achieve the objectives of the EU CAP.

In addition to supporting the agrarian sector, the CAP supports local producers from the national budgets of the member countries of the European Union.

In our country, state support for agriculture is carried out within the framework of the program of state support to the agrarian sector of the economy. In the Russian Federation, just like in the European Union, there is a program to support the agricultural sector, called the State Program for the Development of Agriculture and Regulation of the Markets for Agricultural Products, Raw Materials and Food for 2013-2020, which includes the support program "Sustainable development of rural areas for 2014-2017 and for the period until 2020".

The cardinal difference between the state support of European and Russian agrarians is the lack of supranational support for agriculture in the Russian Federation. The levels of state support in the Russian Federation and the European Union, calculated as a percentage of GDP, are approximately the same and range from $0.7 \%$ to $2.2 \%$ in different years.

The EU agricultural basic support is provided from the EU budget and accounts for approximately $40 \%$ of the budget of the European Union. The main recipients of funds under the CAP are France $17 \%$ of payments, Germany and Spain $-13 \%$ each, Italy $-11 \%$, the UK $-7 \%$.

The existing support scheme for agriculture in the EU redistributes subsidies to support the agrarian sector in the major countries of Europe. Subsidies paid to new EU members are much less than the subsidies that the major EU members get, and payments per hectare of cultivated land range from 527 euros in Greece to 89 euros in Latvia. The European system of redistribution of funds is 
aimed at maximum protection of sovereign markets and preventing the competitive development of the agricultural sector among the new members of the European Union.

Different volumes of financing determine the difference in prices for agricultural products. More effective support of the main agricultural producers leads to an increase in the production of agricultural products, a reduction in selling prices and the squeezing out of the local markets of new members of the EU products of local farmers.

The level of support by the states of local agricultural producers and the level of the state support expressed in percentage of GDP were compared (Fig. 1).

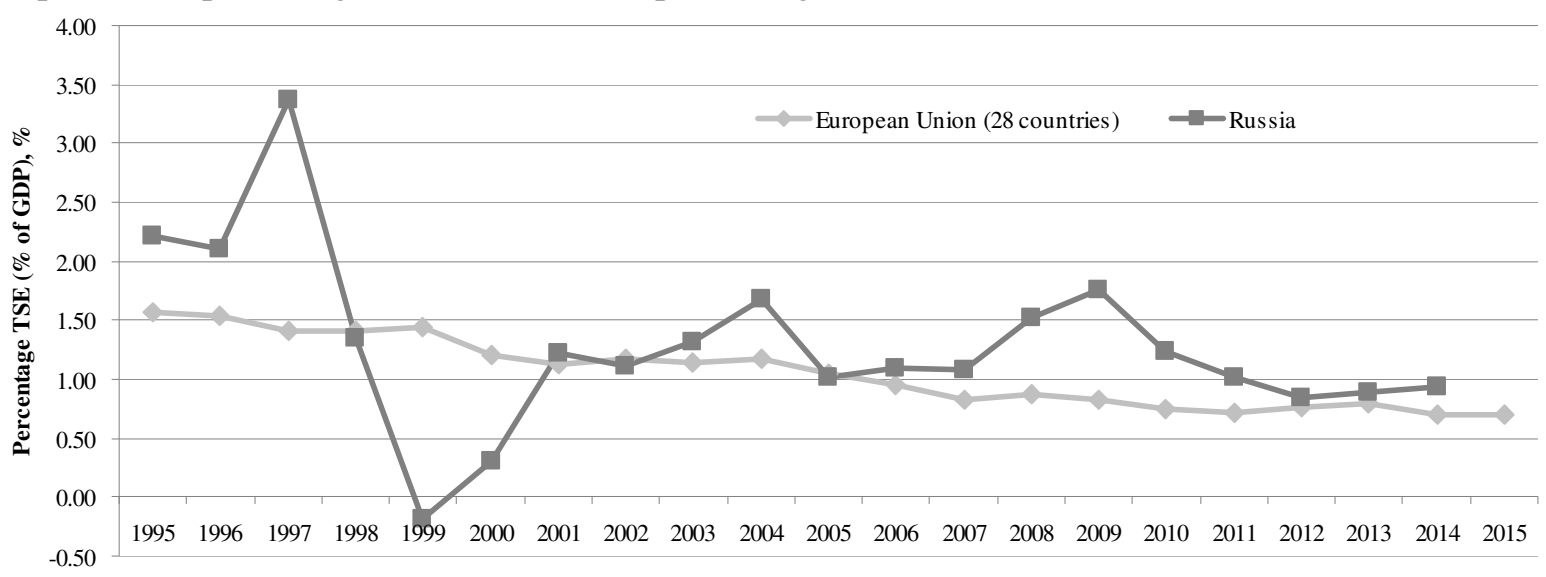

Fig. 1. General support of agriculture by EU member states and Russia (in \% of GDP) [9]

Along with labor and capital, the main means of production in agriculture is land. According to the official website of the European Commission and Eurostat, in 2015 the total area of agricultural land in the European Union was 178.5 million hectares [16]. According to the Ministry of Agriculture of the Russian Federation in 2013, the total area of agricultural land in Russia was 220.2 million hectares. With comparable sizes of areas used by agriculture, the level of support for agriculture in the EU and Russia is significantly different, as Fig. 2 demonstrates.

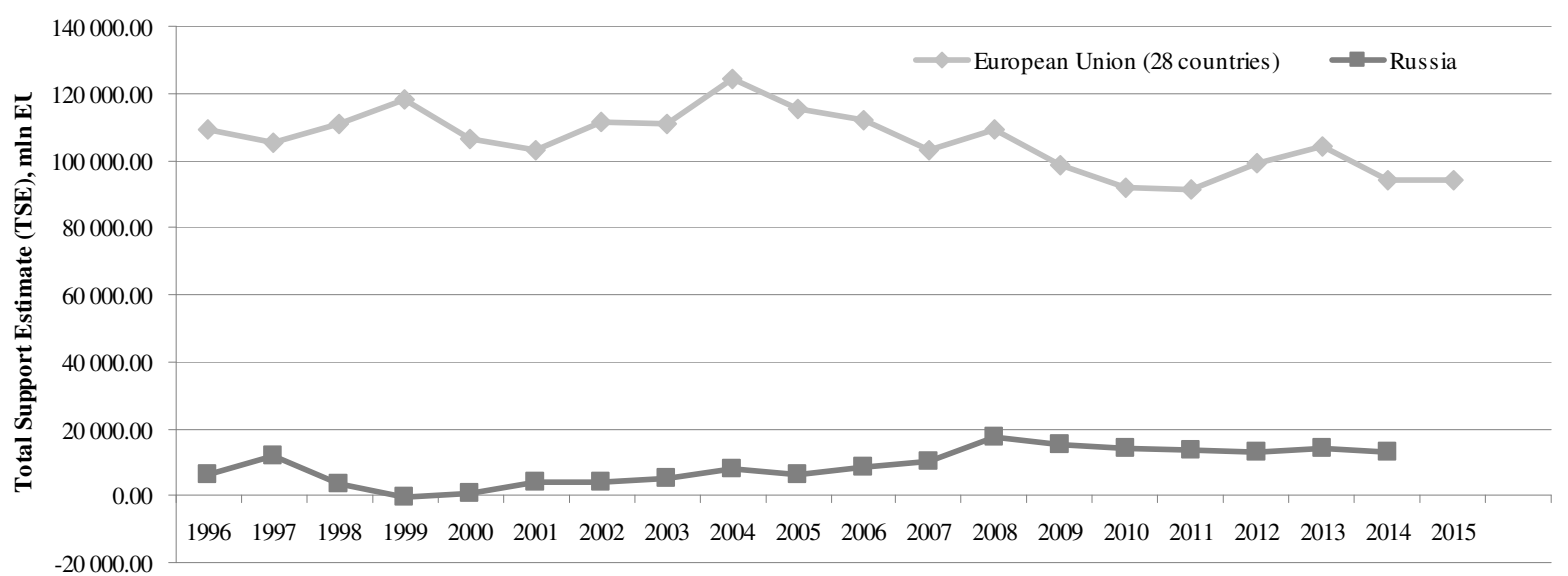

Fig. 2. Total support estimate to agriculture by member States of the EU and Russia (million EUR) [10]

According to the official website of the European Commission and Eurostat in 2015, member States of the European Union on 178,5 million hectares of agricultural land rendered under 93971.69 million EUR of support, which corresponds to 526.5 EUR per hectare of agricultural land. In the Russian Federation according to the same source in 2014, 220.2 million hectares of agricultural land rendered under 13029.83 million Euro support, which corresponds to 59.2 per Euro per hectare of agricultural land, or $8.9 \%$ less than the support provided to member states of the European Union.

\section{Discussion}

With incommensurable levels of state support, the domestic agricultural producer is not in a position to compete with the products of European producers. And in the event of a possible softening 
of the sanction confrontation and, accordingly, the return of European food to the domestic market of Russia without proper state support, the products of Russian farmers can be squeezed out by more competitive products from Europe.

Agricultural support in Russia differs from supporting agricultural producers in other countries, both in terms of support and in the mechanisms for their implementation.

In our country most of the agricultural support is in the form of excess of internal procurement prices on products over the similar prices worldwide.

22 Aug 2012 the Russian Federation joined the world trade organization, membership in which implies a revision of the national support mechanisms for the agricultural sector. The WTO rules prescribe the need to shift from subsidizing depending on the volume of production of specific types of products to subsidize for an impersonal hectare of sowing or head of livestock (in 2010 in the EU $66.1 \%$ of all support was given in the form of subsidies per 1 ha, 1 head of livestock, and in Russia $2.1 \%$ of all support). Another limitation in the WTO membership is the refusal of the Russian Federation to price support through export and import duties, which are imposed on specific types of products [3].

According to Ushachev I.G. in the short term, Russia could become one of the largest producers of agricultural products and one of the most important food exporters. Taking into account the growth, up to the recommended rational norms, consumption of agricultural products: grain, vegetable oil, sugar, pork and poultry meat, eggs, according to the calculations of the Russian Academy of Sciences, with the competent use of the agrarian potential of Russia, the country could not only carry out import substitution of agricultural products with its own production, but also when creating a comfortable economic climate, occupy the significant amount of the export market [16].

In this regard, it is advisable to take the following measures:

1. Preferential agricultural insurance of all the sowing areas without exception. This form of support is very effective and does not contradict the WTO rules.

2. Return of excise paid by farmers in the purchase of fuels and lubricants. Export of agricultural products occurs at world prices, a significant decrease in food prices was not accompanied by a decrease in the cost of fuels in the domestic market, which negatively affects the final cost of domestic products, as competitors, using cheap fuels, bear lower costs.

3. The development of the rural infrastructure will provide substantial support to the agro-industrial complex and will not contradict the commitments undertaken by the Russian Federation in the WTO framework.

\section{Conclusions}

Competent state support on the basis of conservative scenarios will be able to restore the efficiency of the agro-industrial complex and with internal growth of consumption of agricultural products preserve the country's food security, increase income and reduce unemployment in rural areas [13].

This study confirms the need to strengthen state support for Russian agriculture both in terms of the amount of support and structure. At the same time, quantitative support should be increased to a comparable level with Europe, structurally - to shift the emphasis on measures that contribute to maximizing the competitiveness of agricultural products in the process of import substitution.

\section{Recommendations}

1. The key criterion for state support of agriculture is the competitiveness of agricultural products in the market, estimated from the standpoint of the ability to compete freely with imported food.

2. It is proposed to calculate the amount of state support from the standpoint of its equivalence with the amount of state support for a specific type of imported food, which constitutes the main share in the import of this type of food in the domestic market.

3. For state support of agriculture to be effective as a driver of import substitution, it is necessary to build state support measures from the standpoint of the priority of measures to stimulate the expansion of production capacities for the production of import-substituting products. To do this, 
it is advisable to support investment projects in agriculture, innovative activities of agricultural producers and the initiative of small businesses.

\section{References}

[1] Basayev B.B. Strategy of machine-technological modernization of regional agriculture / BB Basaev I.B. Basaev // Izvestiya Gorsky State Agrarian University. 2012. Vol. 49. No. 3. pp. 387-396.

[2] Bulletin of the Altai State Agrarian University Zimina, N.A. Shevchuk Publishing House: Altai State Agrarian University (Barnaul) ISSN: 1996-4277 №3 (113) 2014, 187 p.

[3] Falkovich E.B. Features of the EU agricultural policy and ways to improve it. Scientific works Sworld. 2012, 34 (1), pp. 78-82.

[4] Federal Service of State Statistics [online][01.03.2017] Available at: http://www.gks.ru/free_doc/doc_2016/osn-sx15.rar.

[5] Kashin V.I. Food security. History and Modernity // "Academy of Trinitarianism", Moscow, El No. 77-6567, publ. 12932.

[6] Mazloev V.Z. Russia and the WTO: the effect of the ruble exchange rate on the feasibility of measures of the agro-food policy of the state / VZ Mazloyev, A. V. Priemko // Economics of agricultural and processing enterprises. 2012. № 10. pp. 15-18.

[7] Ministry of Agriculture of the Russian Federation [online][01.03.2017] Available at: http://www.mcx.ru/documents/document/show/22732.htm

[8] Ministry of Economic Development of the Russian Federation [online][01.03.2017] Available at: http://economy.gov.ru/minec/about/structure/depmacro/2016260801

[9] Organization of economic cooperation and development [online][01.03.2017] Available at: http://stats.oecd.org/viewhtml.aspx?QueryId $=70971 \& \mathrm{vh}=0000 \& v f=0 \& 1 \& i l=\& l a n g=$ en\#

[10] Organization of economic cooperation and development [online][01.03.2017] Available at: http://stats.oecd.org/viewhtml.aspx?QueryId $=70971 \& \mathrm{vh}=0000 \& v f=0 \& 1 \& i 1=\&$ lang $=$ en\#

[11] Overview of CAP Reform 2014-2020. Agricultural Policy Perspectives Brief $\mathrm{N}^{\circ} 5 * /$ December 2013.

[12]Regional Problems of Economic Transformation Publisher: Noncommercial Partnership "Editorial Board of the Journal" Regional Problems of Economic Transformation "(Makhachkala) ISSN: 1812-7096 №4 2008.

[13] The Agrarian Policy of Modern Russia: Scientific and Methodological Aspects and the Implementation Strategy.- M $\therefore$ VIAPI named after A.A. Nikonova: "The Encyclopedia of Russian Villages", 2015. - p. 7.

[14] The development of the agrarian market in the face of global challenges. Collection of scientific papers. comp. L. V. Laz'ko. Krasnodar, 2016 Publisher: Kuban State Agrarian University (Krasnodar) 2016g.96. p.

[15] Ushachev I.G. Strategic Approaches to the Development of the Agroindustrial Complex of Russia in the Context of International Integration / IG Ushachev. - Moscow: VNIIESH, 2014. - p. 6.

[16] Ushachev I.G. Strategic Approaches to the Development of the Agroindustrial Complex of Russia in the Context of International Integration / The Agrarian Sector of Russia in the Conditions of International Sanctions: Challenges and Answers. - Moscow, RGAU-MAAA them. K.A. Timiryazev 2014. - p. 20. 